\title{
Characterization of Himalayan Rice Genotypes on PPV and FRA Guidelines
}

\author{
Vinaykumar Rachappanavar ${ }^{1 *}$, Jeetendra Kumar Sharma ${ }^{1}$, \\ Himanshu Pandey ${ }^{2}$ and Sabina Rana ${ }^{3}$
}

${ }^{1}$ Department of Seed Science and Technology, Palampur 176062, Himachal Pradesh, India

${ }^{2}$ Department of Plant Biotechnology, UAS, GKVK, Banglore 560065, Karnataka, India ${ }^{3}$ Department of Plant Biotechnology, YSP UHF, Nauni, Solan 173230, HP, India

*Corresponding author

\section{A B S T R A C T}

\begin{tabular}{|c|}
\hline Keywords \\
\hline $\begin{array}{l}\text { Himalayan Rice, } \\
\text { Genotypes, PPV \& } \\
\text { FRA, Guidelines }\end{array}$ \\
\hline Article Info \\
\hline $\begin{array}{l}\text { Accepted: } \\
\text { 22 July } 2018 \\
\text { Available Online: } \\
\text { 10 August } 2018\end{array}$ \\
\hline
\end{tabular}

Genotypes of rice collected from various parts of foot hills of Himalayan region (31.1048 $\left.{ }^{\circ} \mathrm{N} ; 77.1734{ }^{\circ} \mathrm{E}\right)$ mainly Himachal Pradesh were assessed for morphological markers such as leaf linked characters. A significant amount of genetic variation was displayed for most of the traits examined. All genotypes has green coleoptile colour except Kaludhan which was purple in nature. Among the 8 genotypes which having anthocyanin colouration for leaf, 4 genotypes have anthocyanin on tip only, marginal distribution for 3 genotype and uniform spread for Kaludhan. The short leaf blade was found in VL-221 $(26.06 \mathrm{~cm})$ and the longest in HPR-2699 $(56.86 \mathrm{~cm})$. In the genotypes collected, HPR-2143 $(17.80 \mathrm{~mm})$ has the highest leaf width, which was significant superior over all other genotypes. Whereas RP-2421 $(9.90 \mathrm{~mm})$ genotype was found to be the lowest followed by HPR-2746 $(11 \mathrm{~mm})$. These characters can be used for identification of off types at the time of field inspection. Genetic diversity among some of these cultivars indicating that the cultivars can effectively contribute to the gene pool of rice cultivars.

\section{Introduction}

Rice is an important cereal crop of Himachal Pradesh next only to maize during kharif season. Rice accounts for $0.78 \mathrm{~m}$ ha of area and $1.32 \mathrm{~m}$ ton of production on total food grain basis and $22.2 \%$ of area and $18.8 \%$ of production on kharif season crops basis in the State. Kangra and Mandi districts alone account for 71.2 percent of area and 69.7 percent of production. There is great diversity of agro-climatic conditions under which rice is cultivated and its cultivation extends from foot-hills (350 m) to high hills (up to $2300 \mathrm{~m}$ ).
In the high hills of Himachal Pradesh commonly cultivated traditional rice varieties are Jatoo, Matali, Laldhan, Deval, Chohatoo and Sukara dhan etc. People in the high hills prefer rice, which cooks sticky. In Kullu valley and high hills of Shimla and Sirmor districts, these landraces have very specific climatic adoptability. Red rice (red pericarp) is still being grown because of local preferences and fetch premium price (Rana et al., 2000). Classification of genotype on the basis of their morphological traits related to plant anatomy, which final added valve in crop production. These activities are performed at different 
stages of the global process including seed production and scientific research for improvement of crops. The earliest attempt was made for detailed classification of rice varieties based on agronomical and physiological characters by Kikkawa (1921) and Based on leaf sheath colour and then on grain dimension (graham 1913).

\section{Materials and Methods}

The field experiment was conducted at Rice and Wheat research Centre, CSKHPKV, Malan. Which is situated at an elevation of 950 MSL (N $32^{\circ} 07^{\prime}, \mathrm{E}^{\circ} 6^{\circ} 23^{\prime}$ ') coming under sub-humid mid-hill condition. The annual rainfall is $1800 \pm 512 \mathrm{~mm}$. The field experiment was laid out in a randomized block design with 3 replication involving thirty varieties (Table 1) with spacing $20 \times 15 \mathrm{~cm}$. along with application of recommended dose nutrients complex (90: 40: $40 \mathrm{~N}: \mathrm{P}: \mathrm{K} \mathrm{kg} / \mathrm{ha}$ ). To study the plant morphological traits, each genotype were observed for stable and distinguishable characters related to leaf structure as recommended by Plant Varieties and Formers Rights Authority (PPV\&FRA) guidelines (Anon., 2001) and various traits where recorded at different plant growth stages (Table 2).

\section{Results and Discussion}

Broadly the leaf characters can be taken for categorizing are intensity of green colour of leaf, Pubescence of leaf blade, flag leaf blade attitude, ligule shape, leaf blade length, intensity of green colour of leaf, density of pubescence on lemma (Table 2). For on the intensity of green colour of leaf, 5 had light green, 13 with medium and 10 genotypes with dark green leaves Monika et al., (2007) also clustered nineteen genotype of paddy based on intensity of green colour of leaf. It was absent in all the cultivars of his study. Similar type of work was carried out by Anita Lakshmi
(2002), Nethra (2003), Rimpi et al., (2008), Mageshwaran (2010) and Sarika et al., (2011).

All genotypes has green coleoptile colour (Fig. 1) except Kaludhan which was purple in nature. The sheath colour for Basel leaf (Fig. 2 and 3) was observed, 25 genotypes are found in having green colour, 2 are light purple and 3 are purple for leaf sheath colour. Similar work was carried out by Monika et al., 2007 by grouping all 19 varieties into green basel leaf colour. Among the 8 genotypes which having anthocyanin colouration for leaf (Fig. 4), 4 genotypes have anthocyanin on tip only, marginal distribution for 3 genotype and uniform spread for Kaludhan. With respect to the presence or absence of pubescence on blade surface of leaf varied among the genotypes. Jhinidhan didn't have pubescence on the leaf sheath and very strong in HPR2682. Mangeshwaran (2010) also grouped 10 genotypes based on this pubescence character. Auricles are present in all genotypes. Among these HPR-2711 and Jhinidhan having purple anthocyanin colouration for auricle. Monika et al., (2017) also grouped 19 varieties on this character basis.

In all genotypes, color (Fig. 5) and ligule are present.HPR-2748, Kalijhini-1; Kalijhini-2 has anthocyanin colouration for collar (Fig. 6 and 7). Ten genotypes were acute for ligule shape and others are split in nature. According to Bora et al., (2018) among 19 varieties, 11 are split in shape for ligule for which DUS characterization was done. The short leaf blade was found in VL-221 $(26.06 \mathrm{~cm})$ and the longest in HPR-2699 $(56.86 \mathrm{~cm})$. In the genotype collected HPR-2143 (17.80mm) has the highest leaf width, which was significant superior over all other genotypes. Whereas RP-2421 (9.90 mm) genotype was found to be the lowest followed by HPR-2746 (11 mm). Rosita (1975) suggested that length and width of blade were quite useful traits in varietal identification. 
Table.1 Rice cultivars and their source

\begin{tabular}{|c|c|c|c|c|}
\hline $\begin{array}{l}\text { Sr. } \\
\text { No. }\end{array}$ & Varieties & Source & $\begin{array}{l}\text { Year of } \\
\text { release }\end{array}$ & Source/Pedigree \\
\hline 1. & HPR-1068 & $\begin{array}{l}\text { CSKHPKV, } \\
\text { Palampur }\end{array}$ & 2005 & $\begin{array}{l}\text { IR 53455Nag- 11-1-12-1-3 IR } \\
42015-83-3-22 \times \text { IR 9758-K2 }\end{array}$ \\
\hline 2. & $\begin{array}{l}\text { HPR-2720 (Palam } \\
\text { Lal Dhan-1) }\end{array}$ & Do & 2013 & $\begin{array}{l}\text { Pure line selection from } \\
\text { IC } 455333\end{array}$ \\
\hline 3. & $\begin{array}{l}\text { HPR-2612(Palam } \\
\text { Basmati-1) }\end{array}$ & Do & 2013 & Sarai/T23 × IR 66295-36-2 \\
\hline 4. & KASTURI & Do & 1994 & Basmati $370 \times$ CRR 88-17-1-5 \\
\hline 5. & HPR-1156 & Do & & $\begin{array}{l}\text { IR 32429122-3-1-2 × IR } \\
31868-64-2-33-3\end{array}$ \\
\hline 6. & $\begin{array}{l}\text { HPR-2880(Him } \\
\text { Palam Dhan-2) }\end{array}$ & Do & 2016 & HPU2216 × Tetap \\
\hline 7. & $\begin{array}{l}\text { HPR-2656(Him } \\
\text { Palam Dhan-1) }\end{array}$ & Do & 2016 & RP2421 $\times$ Tetap \\
\hline 8. & RP-2421 & Do & 1994 & IR36 $\times$ Kanthawar \\
\hline 9. & VL-221 & Do & 1994 & IR-2053-521-1-1-1 × CH-1039 \\
\hline 10. & HPR-2143 & Do & 2005 & $\begin{array}{l}\text { HPR 9020-22-2-1-1-1 Phul } \\
\text { Patas } \times \text { HUP } 741\end{array}$ \\
\hline 11. & HPR-2682 & Do & $\begin{array}{l}\text { Improved } \\
\text { lines }\end{array}$ & Him dhan-1 × IR-53915 \\
\hline 12. & HPR-2687 & Do & do & $\begin{array}{l}\text { VL Dhan-221 x RP2421 xx } \\
\text { IR53925 }\end{array}$ \\
\hline 13. & HPR-2697 & Do & do & $957 \times$ RP-2421 \\
\hline 14. & HPR-2699 & Do & do & RP-2421 x VL dhan-221 \\
\hline 15. & HPR-2707 & Do & do & VL dhan-221 $\times$ JD-3 \\
\hline 16. & HPR-2711 & Do & do & TS-29 × HPV-2216 \\
\hline 17. & HPR-2766 & Do & do & HIM-1 × IR-53915 \\
\hline 18. & HPR-2748 & Do & do & Hessan Serai $\times$ T23 ×IR66295 \\
\hline 19. & HPR-2746 & Do & do & $\begin{array}{l}\text { Hessan Serai ×T23 } \\
\times \times \text { IR66295-36-2 }\end{array}$ \\
\hline 20. & Chinudhan & Jandrangal & Landraces & Villege-Jandrangal \\
\hline 21. & Jhinidhan & Timber & do & Pritam Chand. Dadh-Timber \\
\hline 22. & Saaldhan & Bir & do & Bachtan Singh Villege-Bir \\
\hline 23. & Sailadhan & Keor & do & Surjadevi. Villege-Keor \\
\hline 24. & Kaludhan & Pangal & do & Pratap Singh-Pangal \\
\hline 25. & Kalijhini-1 & Jadrangal & do & Villege-Jadrangal \\
\hline 26. & Kalijhini-2 & Indragal & do & Shyam Lal-Indragal \\
\hline 27. & Ramjawandhan & Nagarota & do & Bagawan -Nagarota \\
\hline 28. & Sukara & Bhatiyala & do & Bhatiyat- Chamba \\
\hline 29. & Chohartu & Rohru & do & Rohru, Shimla \\
\hline 30. & Karad & Dadryada & do & Chamba \\
\hline
\end{tabular}


Table.2 Description of qualitative characters based on DUS and PPVFRA guidelines

\begin{tabular}{|c|c|c|c|c|}
\hline $\begin{array}{l}\text { S. } \\
\text { No. }\end{array}$ & $\begin{array}{l}\text { Growth } \\
\text { Stage }\end{array}$ & Characters & Category or types & No of genotypes \\
\hline 1. & VS & Coleoptile: colour & $\begin{array}{l}\text { 1. Colourless } \\
\text { 2. Green } \\
\text { 3. Purple }\end{array}$ & $\begin{array}{c}0 \\
29 \\
1\end{array}$ \\
\hline 2. & VS & Basal leaf: sheath colour & $\begin{array}{l}\text { 1. Green } \\
\text { 2. Light purple } \\
\text { 3.Purple lines }\end{array}$ & $\begin{array}{c}25 \\
2 \\
3\end{array}$ \\
\hline 3. & VG & $\begin{array}{l}\text { Leaf: intensity of green } \\
\text { colour }\end{array}$ & $\begin{array}{l}\text { 3. Light } \\
\text { 5. Medium } \\
\text { 7. Dark }\end{array}$ & $\begin{array}{c}4 \\
12 \\
16\end{array}$ \\
\hline 4. & VG & Leaf: anthocyanin colour & $\begin{array}{l}\text { 1. Absent } \\
\text { 9. Present }\end{array}$ & $\begin{array}{c}22 \\
8\end{array}$ \\
\hline 5. & VG & $\begin{array}{l}\text { Leaf: distribution of } \\
\text { anthocyanin colour }\end{array}$ & $\begin{array}{l}\text { 1. On tips only } \\
\text { 2. On margins only } \\
\text { 3. On blotches only } \\
\text { 4. Uniform }\end{array}$ & $\begin{array}{l}4 \\
3 \\
0 \\
1\end{array}$ \\
\hline 6. & VG & $\begin{array}{l}\text { Leaf sheath: anthocyanin } \\
\text { colour }\end{array}$ & $\begin{array}{l}\text { 1. Absent } \\
\text { 9. Present }\end{array}$ & $\begin{array}{l}20 \\
10\end{array}$ \\
\hline 7. & VG & $\begin{array}{l}\text { Leaf sheath: intensity of } \\
\text { anthocyanin colour }\end{array}$ & $\begin{array}{l}\text { 1. Very weak } \\
\text { 3. Weak } \\
\text { 5. Medium } \\
\text { 7. Strong } \\
\text { 9. Very strong }\end{array}$ & $\begin{array}{l}2 \\
2 \\
0 \\
6\end{array}$ \\
\hline 8. & VS & $\begin{array}{l}\text { Leaf: pubescence of blade } \\
\text { surface }\end{array}$ & $\begin{array}{l}\text { 1. Absent } \\
\text { 3. Weak } \\
\text { 5. Medium } \\
\text { 7. Strong } \\
\text { 9. Very strong }\end{array}$ & $\begin{array}{c}1 \\
8 \\
10 \\
10 \\
1\end{array}$ \\
\hline 9. & VS & Leaf: auricles & $\begin{array}{l}\text { 1. Absent } \\
\text { 9. Present }\end{array}$ & $\begin{array}{c}0 \\
30\end{array}$ \\
\hline 10 & VS & $\begin{array}{l}\text { Leaf: anthocyanin colour of } \\
\text { auricles }\end{array}$ & $\begin{array}{l}\text { 1. Colourless } \\
\text { 2. Light purple } \\
\text { 3. Purple }\end{array}$ & $\begin{array}{c}26 \\
2 \\
2\end{array}$ \\
\hline 11. & VS & Leaf: collar & $\begin{array}{l}\text { 1. Absent } \\
\text { 9. Present }\end{array}$ & $\begin{array}{c}0 \\
30\end{array}$ \\
\hline 12. & VS & $\begin{array}{l}\text { Leaf: anthocyanin colour of } \\
\text { collar }\end{array}$ & $\begin{array}{l}\text { 1. Absent } \\
\text { 9. Present }\end{array}$ & $\begin{array}{c}27 \\
3\end{array}$ \\
\hline 13. & VS & Leaf: ligule & $\begin{array}{l}\text { 1. Absent } \\
\text { 9. Present }\end{array}$ & $\begin{array}{c}0 \\
30\end{array}$ \\
\hline 14. & VS & Leaf: shape of ligule & $\begin{array}{l}\text { 1. Truncate } \\
\text { 2. Acute } \\
\text { 3. Split }\end{array}$ & $\begin{array}{c}0 \\
9 \\
21\end{array}$ \\
\hline 15. & VS & Leaf: colour of ligule & $\begin{array}{l}\text { 1. White } \\
\text { 2. Light purple } \\
\text { 3. Purple }\end{array}$ & $\begin{array}{c}24 \\
4 \\
2\end{array}$ \\
\hline 16. & MS & $\begin{array}{l}\text { Leaf: length } \\
\text { of blade }\end{array}$ & $\begin{array}{l}\text { 3. Short }(<30 \mathrm{~cm}) \\
\text { 5. Med }(30-45 \mathrm{~cm}) \\
\text { 7. Long }(>45 \mathrm{~cm})\end{array}$ & $\begin{array}{c}1 \\
25 \\
4\end{array}$ \\
\hline 17. & MS & Leaf: width of Blade & $\begin{array}{l}\text { 3. Narrow }(<1 \mathrm{~cm}) \\
\text { 5. Medium }(1-2 \mathrm{~cm}) \\
\text { 7. Broad }(>2 \mathrm{~cm})\end{array}$ & $\begin{array}{c}1 \\
29 \\
0\end{array}$ \\
\hline 18. & VG & $\begin{array}{l}\text { Flag leaf: attitude of blade } \\
\text { (early observation) }\end{array}$ & $\begin{array}{l}\text { 1. Erect } \\
\text { 3. Semi-erect } \\
\text { 5. Horizontal } \\
\text { 7. Drooping }\end{array}$ & $\begin{array}{c}20 \\
9 \\
1 \\
0\end{array}$ \\
\hline
\end{tabular}


Fig.1 Schematic diagram for cultivar identification of rice varieties on the Basis of seed characters

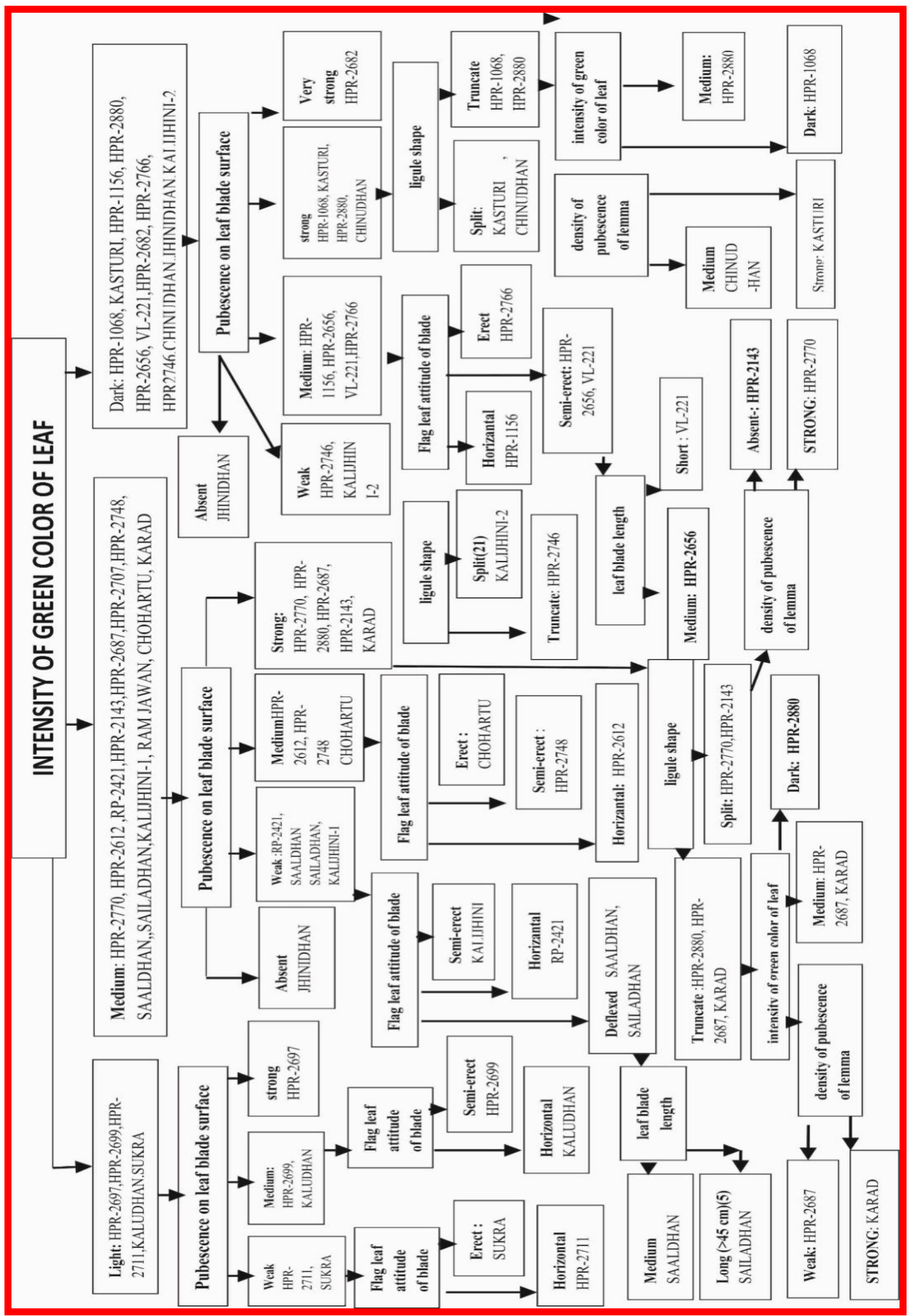




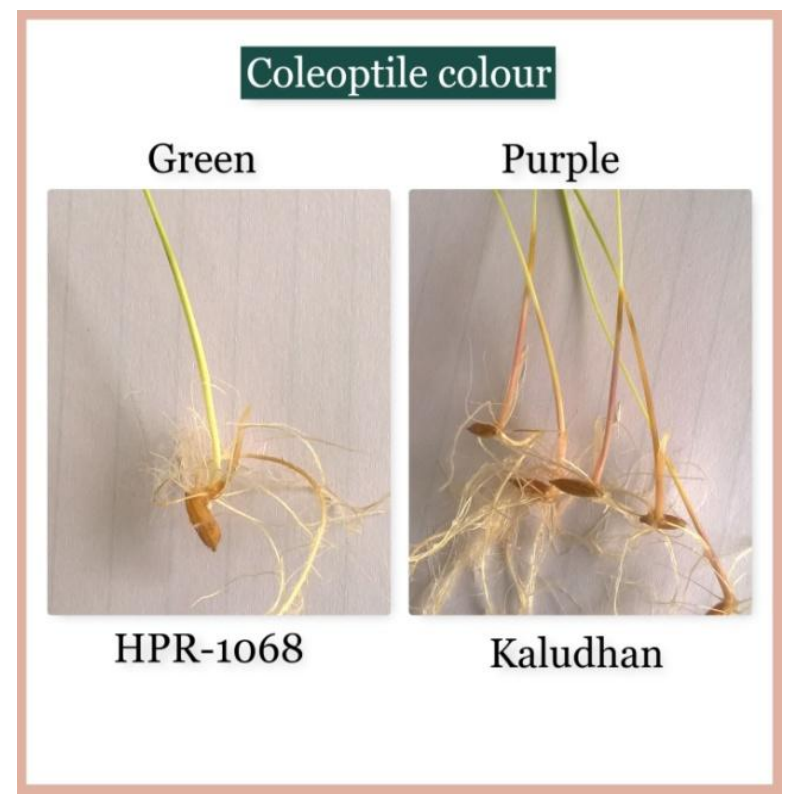

Fig.1 Characterization of rice varieties on the basis of coleoptile colour

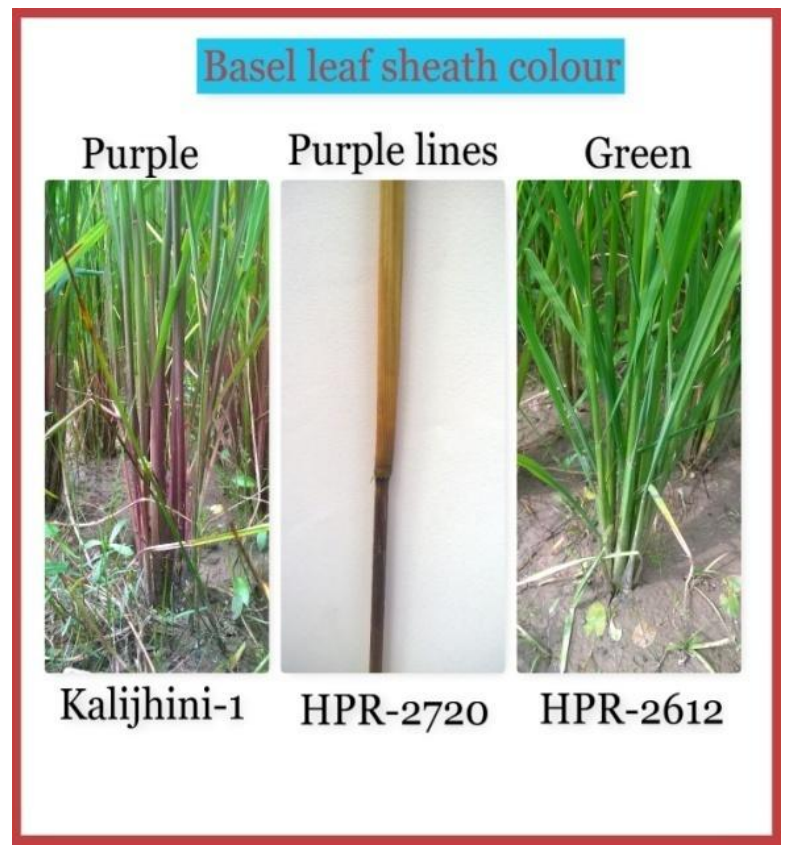

Fig.3 Characterization of rice varieties on the basis of basal leaf sheath anthocyanin colouration

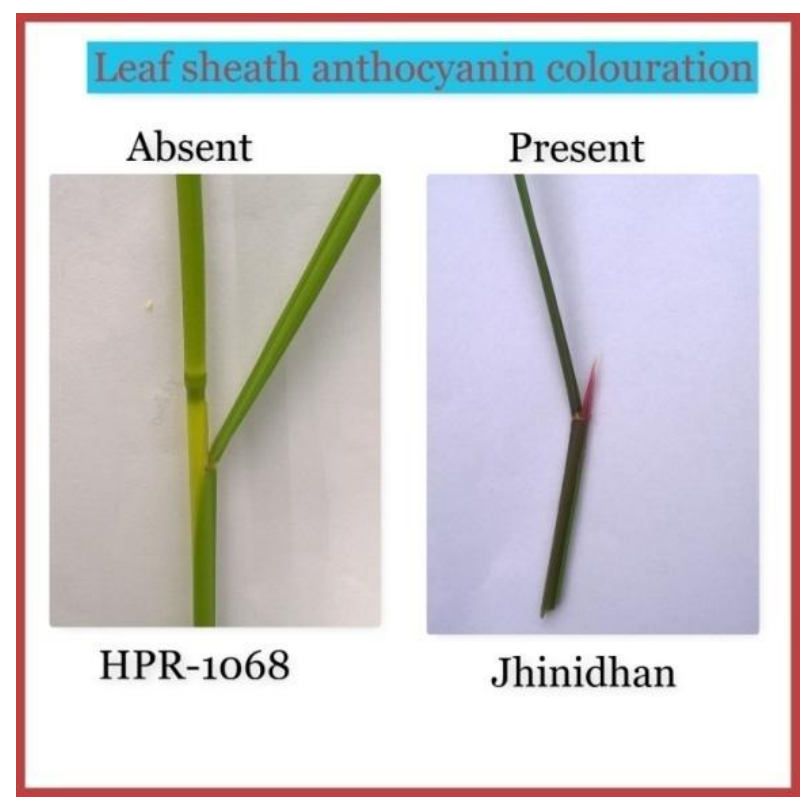

Fig.2 Characterization of rice varieties on the basis of basal leaf sheath colour

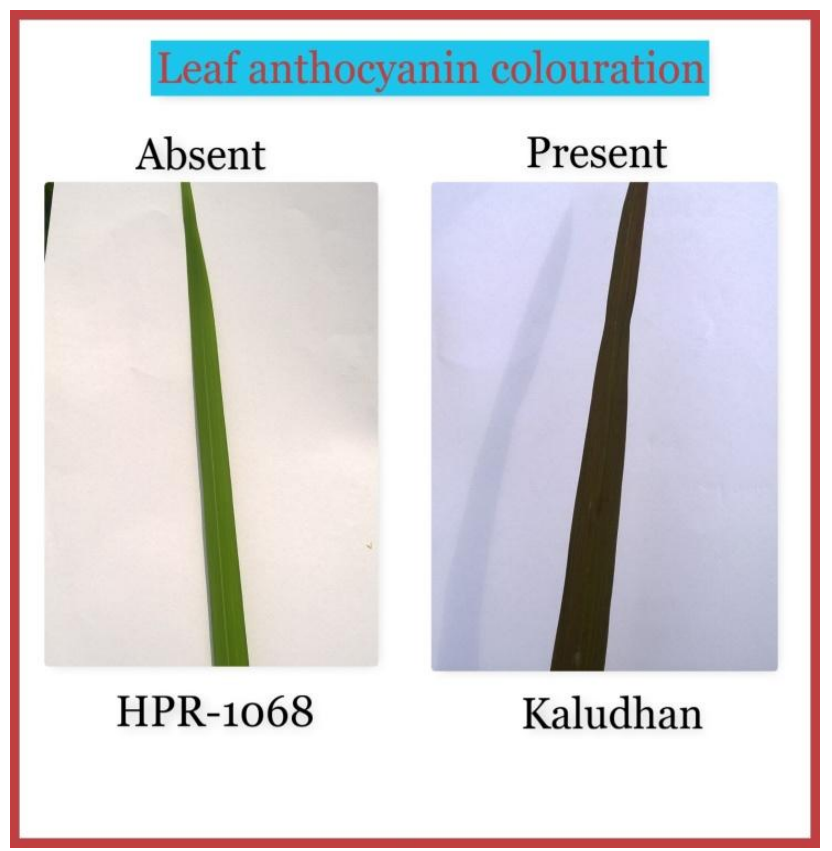

Fig.4 Categorization of paddy varieties on the basis of leaf anthocyanin colour 


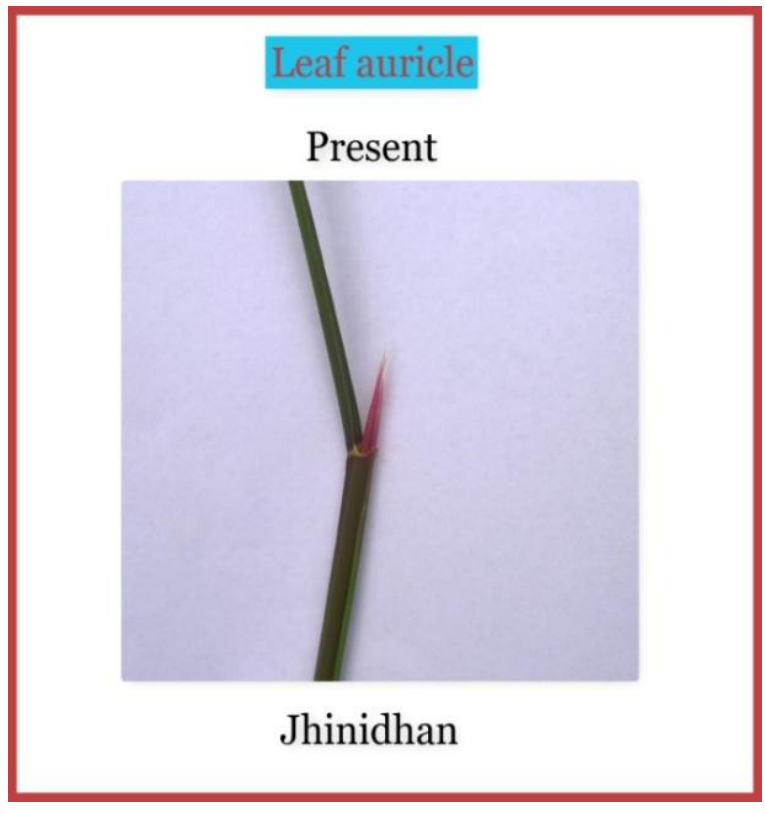

Fig.5 Characterization of rice varieties on the basis of presence leaf auricles

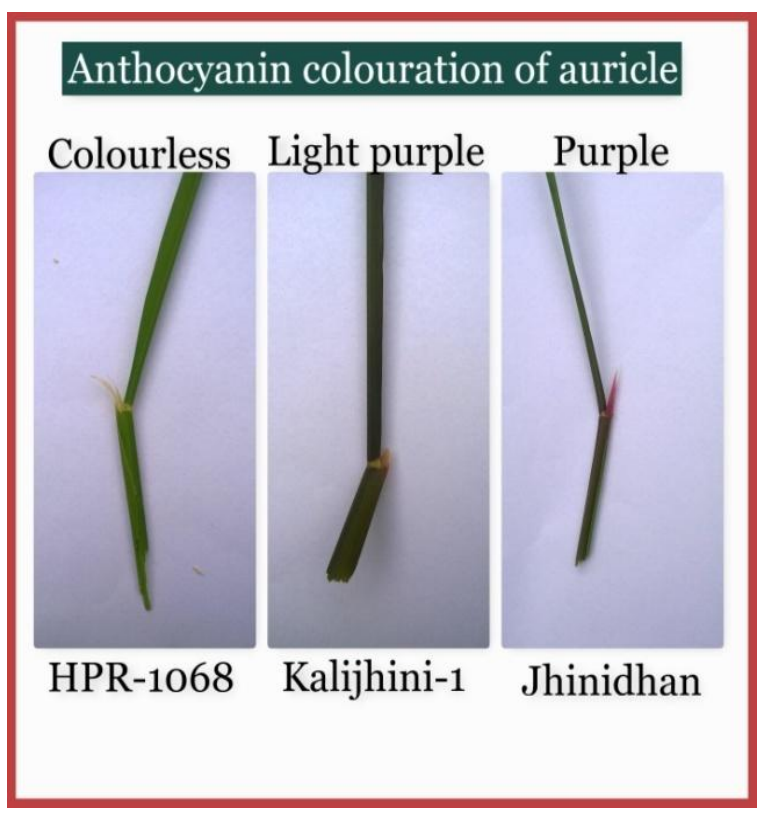

Fig.6 Characterization of rice varieties on the basis of basal of anthocyanin colouration of auricles

\section{Leaf :anthocyanin colouration of collar}

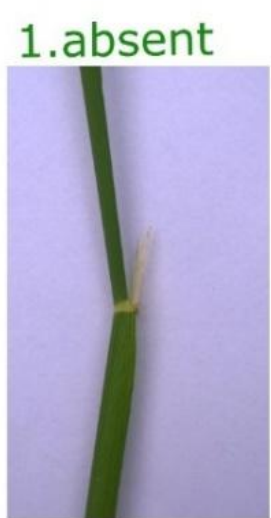

HPR-1068 9.present

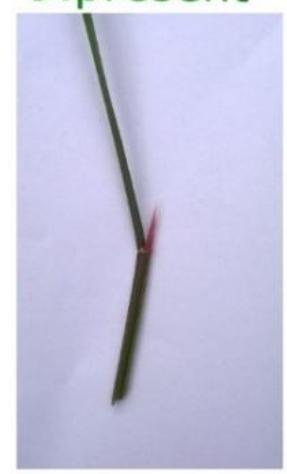

JHINDHAN

Fig.7 Characterization of rice varieties on the basis of anthocyanin colouration of collar 


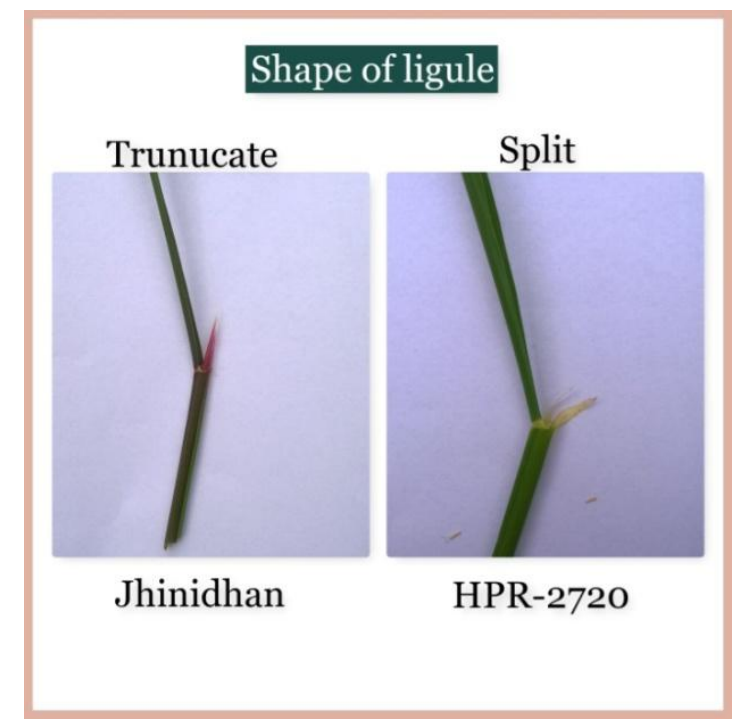

Plate.8 Characterization rice varieties on the basis of basal shape of ligule

Attitude of flag leaf

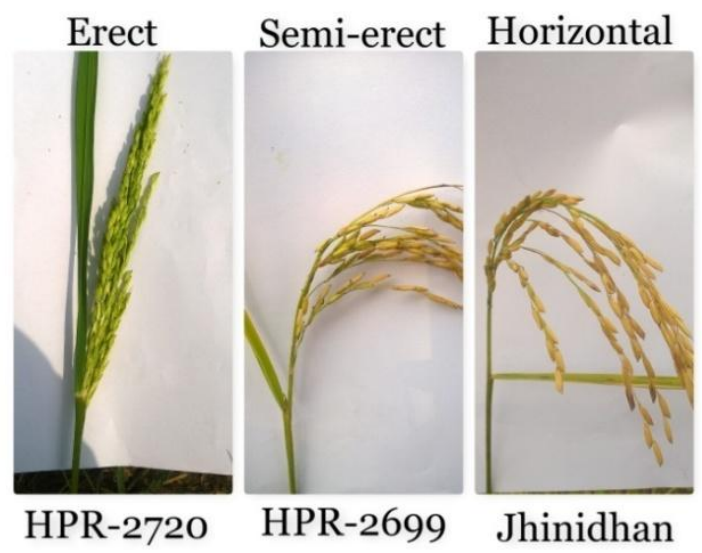

Plate.10 Characterization of rice varieties on the basis of attitude of blade

Monika et al., (2007) also grouped nineteen rice varieties based on length and width of the blade and suggested that high heritability and genetic advance (GA) was found with references to these characters. Attitude of blade were observed both at early (Beginning of a thesis) and later stage (ripening) of crop growth but later stage observation is best for characterization of genotypes. At later stage observation, Except RP-2421 and VL-221 (semi-erect), all are erect in nature.

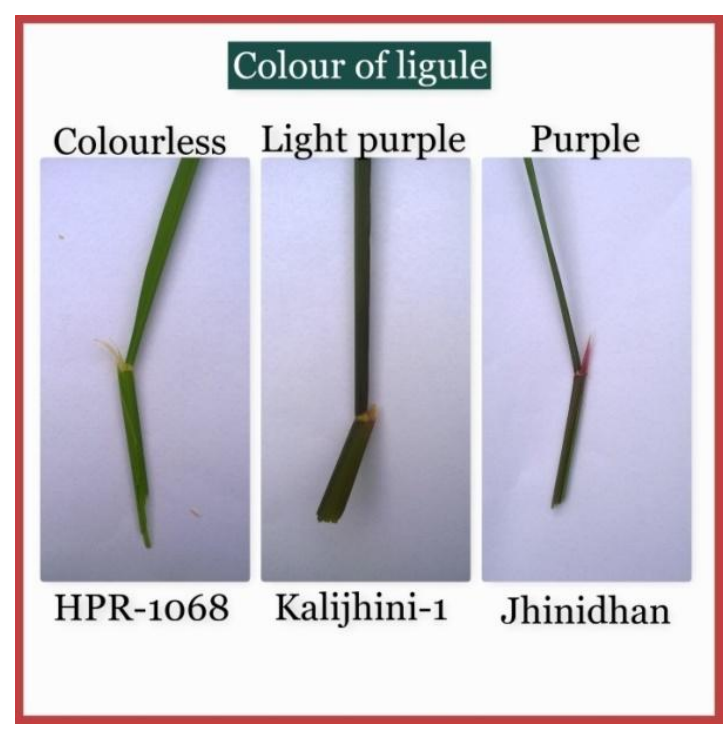

Plate.9 Characterization of rice varieties on the basis of presence colour of ligule

\section{anthocyanin colouration of area below apex}

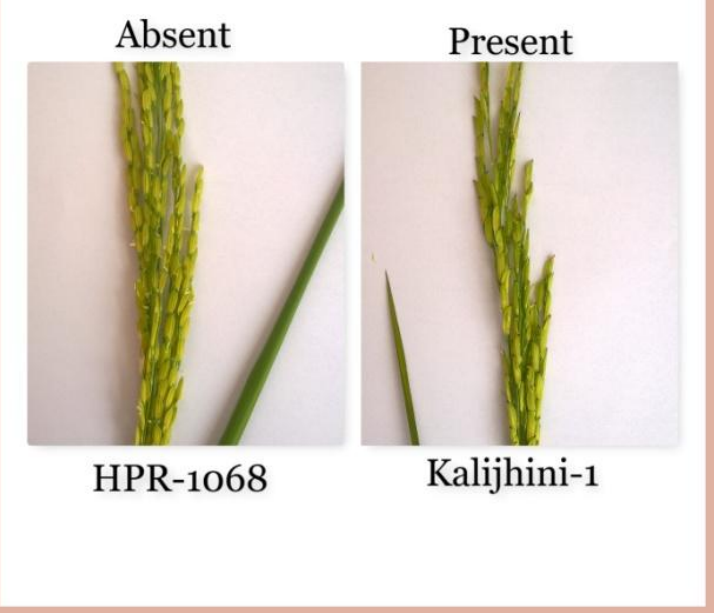

Plate.11 Characterization of rice varieties on the basis of anthocyanin colouration of area below apex

On the basis of results, It can be concluded that morphological DUS description can be effectively used for identification, documentation and grouping of varieties along with their use in registration and unambiguous identification in the field.

\section{References}

Anitalakshmi V. Characterization and identification of cultivars based on 
morphological and biochemical markers in rice (Oryza sativa L.). M.Sc. (Agri.) Thesis submitted to the Univ. Agric. Sci., Bangalore, Karnataka (India). 2002.

Anonymous. 2008. Centre for monitoring Indian Economy, Mumbai.

Bora R, Deka SD and Sen P. Identification of rice varieties of Assam, based on grain characters and reaction to certain chemical tests. Seed Res, 2008, 36(1): 51- 55 .

Graham RJD. Preliminary note of the classification of rice in the central provinces. Meni. Dept. Agric. India Botanical Survey, 1913, 6, 209-229.

Kikkawa S. On the classification of cultivated rice. Journal of College of Agriculture, Tokyo, 1913, 3, 1-108.

Mageshwaran S. 2010. Evaluation of Morphological, chemical and biochemical methods for cultivar identification in rice (Oryza sativa L.) M.Sc. (Agri) Thesis, Tamil Nadu Agric. Univ., Coimbatore, Tamilnadu (India).

Monika A, Joshi A, Navaraj K, Sharma RC, Singh $P$ and Bharaj TS. Varietal characterization of rice (Oryza sativa L.) based on morphological descriptors. Seed Res, 2007, 35(2), 188-193.
Nethra N. 2003. Studies on varietal characterization based on morphological, biochemical and molecular markers in rice. M.Sc. (Agri) Thesis, Univ. Agric. Sci., Bangalore, Karnataka (India).

Rana RB, Chaudhary P, Gaudhan D, Khatiwada SP, Sthapit BR and Subedi A. 2000. In situ crop conservation: findings of agro-ecological, crop diversity and socio-economic baseline survey of Kachorwa eco-site, Bara, Nepal. NARC and LI-BIRD, Nepal/IPGRI, Rome, Italy NP Working Paper No. 1/2000

Rimpi Bora, Sharmia Dutta Deka and Abrata Sen. Characterization of local rice varieties of Assam using morphological markers, Seed Res, 2008, 36(2), 218227.

Sarika Mathur, Asif Shaikh, N., Renuka, Kantilal Wakte, Narendra Jawali, Ratnakar Thengane and Altafhusain Nadaf. Characterisation of aromatic rice (Oryza sativa L.) germplasm and correlation between their agronomic and quality traits. Euphytica, 2011, 179, 237-246.

\section{How to cite this article:}

Vinaykumar Rachappanavar, Jeetendra Kumar Sharma, Himanshu Pandey and Sabina Rana. 2018. Characterization of Himalayan Rice Genotypes on PPV and FRA Guidelines. Int.J.Curr.Microbiol.App.Sci. 7(08): 4198-4206. doi: https://doi.org/10.20546/ijcmas.2018.708.439 